\title{
Neogene evolution of the Aegean arc: paleomagnetic and geodetic evidence for a rapid and young rotation phase
}

\author{
C.E. Duermeijer*, M. Nyst, P.Th. Meijer, C.G. Langereis, W. Spakman \\ Vening Meinesz research School of Geodynamics, Faculty of Earth Sciences, Utrecht University, Budapestlaan 17, \\ 3584 CD Utrecht, The Netherlands
}

Received 21 June 1999; received in revised form 21 January 2000; accepted 21 January 2000

\begin{abstract}
New paleomagnetic data of the entire Aegean outer-arc are presented. The results indicate a young Pleistocene and rapid clockwise rotation phase in the western Aegean arc, covering at least Zakynthos and the Peloponessos. The eastern Aegean arc, incorporating Kassos, Karpathos and Rhodos, also experienced Pleistocene anticlockwise rotations. The anisotropies of the magnetic susceptibility (AMS) data are in agreement with arc-parallel extension in the south and south-eastern Aegean arc and arc-normal compression in the north-west, in agreement with structural and geodetic observations. We compare the paleomagnetic results with the present-day pattern of rotation as computed from geodetic data, and we find good agreement. The onset of the Pleistocene rotations coincides with the beginning of uplift and a change in the stress pattern of extension. We compare our findings with existing models for the Aegean area. (C) 2000 Elsevier Science B.V. All rights reserved.
\end{abstract}

Keywords: paleomagnetism; geodesy; tectonics; rotation; Aegean Islands; Neogene

\section{Introduction}

Many paleomagnetic studies have contributed to the reconstruction of the Neogene evolution of the Aegean area [1-6]. Kissel and Laj [2] have postulated an evolution for the Aegean arc with an almost rectilinear (E-W) starting configuration between the Paleocene and the late Burdigalian. During the middle Miocene, the western

\footnotetext{
* Corresponding author. Fax: +31-30-2531677;

E-mail: duermeij@geo.uu.nl
}

(Epirus, NW Greece) and eastern Aegean arc (Bey-Daglari, SW Turkey) started to rotate clockwise, respectively anticlockwise. A second, supposedly continuous, phase of rotation was thought to have occurred only in the western Aegean arc (Ionian islands) during the last $5 \mathrm{Myr}$.

Since the early nineties, astronomical polarity time scales and their related high accuracy biostratigraphy provide the possibility to correlate sections/sites over a large geographic area and to accurately constrain the timing of tectonic events. Aided by these new techniques, we decided to explore the outer Aegean arc. This non-volcanic arc comprises from west to east: Epirus, the Ionian islands (Corfu, Lefkas, Kefallonia, Zakynthos), the Peloponessos, Kythira, Crete, Kassos, Karpa- 
thos and Rhodos (Figs. 1 and 3). In addition, we studied sediments from the central Aegean island of Milos. The present paper describes the synthesis of all our paleomagnetic data derived from the Aegean. We postulate a new tectonic evolution of the Aegean area and compare our results to geodynamic models that have been proposed for the region. Furthermore, we evaluate geodetic data from the region in this new context.

\section{Geology and sampling}

\subsection{Centrallsoutheastern Aegean arc}

We sampled 38 localities (691 cores) of sedimentary rocks in the central/eastern Aegean arc on Rhodos, Karpathos, Kassos, Crete and Milos (Fig. 1). Ages are not very well constrained since most sediments lack an age diagnostic biostratigraphy. The eastern arc islands are characterized by topographic highs consisting mostly of Jurassic to Eocene limestones. On Rhodos, a small ophiolitic and flysh unit of Oligocene age can be found on top of these limestones, surrounded by Miocene to Pleistocene sediments, mostly of continental, fluvio-lacustrine origin, but some shallow marine to beach deposits are present. On Karpathos, the Neogene sediments are restricted to three small basins in the south of the island, consisting of Plio/Pleistocene beach deposits (SW and SE) and of Pliocene shallow marine clays occur (S). Kassos consists mainly of high peaks of strongly deformed limestones, but has two small areas with limestone in the SE and marls and clays in the $\mathrm{W}$, both of Miocene age. On Crete, close to Heraklion, the Messinian limestones are overlain by Pliocene marl-breccias with some intercalations of 'Trubi-like' sediments, on top of which we find Trubi-like sediments with sapropels, followed by shallow marine sandy yellow marls and white diatomites [7]. The complete succession is seen near Prassas (PRA in Fig. 1). Only in the northern Heraklion basin, Pleistocene shallow marine sandy clays and red conglomerates are found. The central part of Crete contains most of the Plio/ Pleistocene sediments on the island and the largest (up to $40^{\circ}$ ) post early Messinian anticlockwise

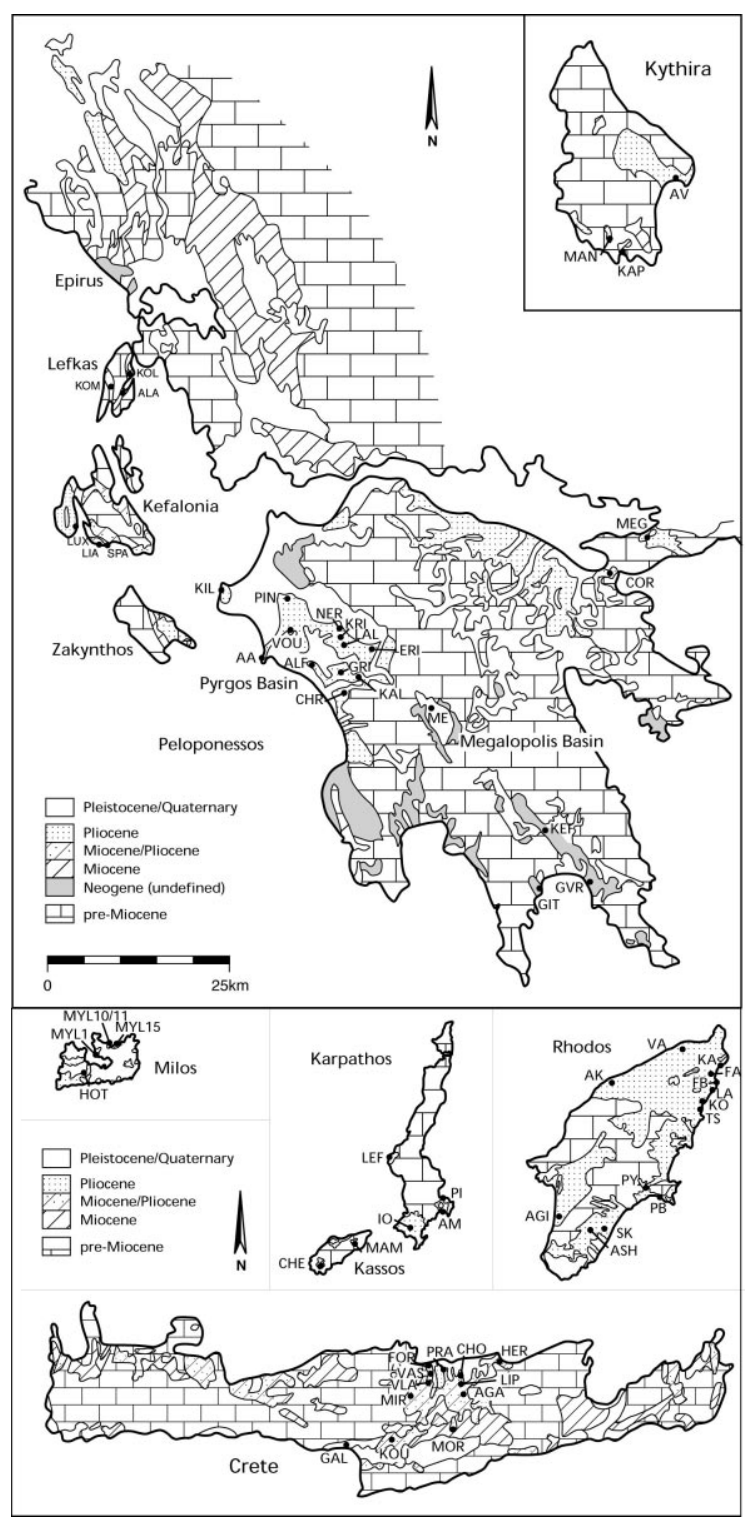

Fig. 1. Simplified geological map of the outer Aegean arc with sample/site localities (see also Appendix 1). For the exact location of sites from Zakynthos we refer to Duermeijer et al. [6].

rotations were detected [5]. The volcanic island of Milos is located more to the internal part of the Aegean arc. This inner-arc island contains Pelagonian basement formed by volcanic rocks of various ages overlain by white tuffites and yellow marls of Plio-Pleistocene age. In the NW of Mi- 
los, a marine section containing a cyclic alternation of early Pliocene silty clays and sapropels was sampled.

\subsection{Western Aegean arc}

In the western Aegean arc we took 52 sites/sections (1912 cores) from Miocene to Pleistocene sediments on the Ionian islands of Lefkas, Kefallonia, Zakynthos, on the Peloponessos and on the island of Kythira (Fig. 1). The western Aegean is characterized by NNW-SSE trending sedimentary units [8] called isopic zones and named from west to east Pre-Apulian, Ionian, Gavrovo-Tripolitsa, Pindos, (Sub)Pelagonian and Vardar. Each unit contains Mesozoic carbonates at its base and is separated from the juxtaposed unit by a major Tertiary thrust. In general, the age of deformation, the degree of metamorphism and tectonism and the age of the oldest rocks exposed within each isopic zone all decrease from east to west [9]. Our sites/sections are mainly from the PreApulian, Ionian and Pindos zones.

Lefkas consists of Jurassic to Eocene limestones, followed by Oligocene to early Miocene limestones alternating with marls or coarser grained material. These sediments are intensely folded and overlain by (scarce outcrops of) early middle Miocene marls with sapropels and middle Miocene turbidities. The Plio-Pleistocene is absent on Lefkas. Kefallonia has a core of Jurassic to Paleogene limestones around which Plio-Pleistocene and some Miocene sediments were deposited. These younger sediments closely resemble the Miocene to Pleistocene sediments of Zakynthos, but on Kefallonia they are more deformed, and they are coarser and thicker, suggesting a similar but more proximal setting. On Zakynthos, sediments range in age from Cretaceous to Pleistocene and occur mostly in approximately parallel NWSE trending zones. On the Peloponessos, not many outcrops of Neogene sediments are exposed; most of the area being covered by Mesozoic limestones. Scattered upper Pliocene outcrops are located in the central-south (silty clay) and south (continental to shallow marine sand with occasional silt layers). In the Pyrgos basin of NW Peloponessos, extensive Plio-Pleistocene open bay to lagoonal sections are outcropping [10]. In the center of the Peloponessos, the intramontane Megalopolis Basin is exposed, containing Pleistocene lacustrine sediments, while in the NE the Corinth and Megara basins are situated. The Megara basin contains Plio-Pleistocene lacustrine, deltaic to fluviatile deposits and is at present bounded by a NW active normal fault. Nearby, the actively extending Corinth basin contains $4 \mathrm{Ma}$ old andesites representing the initiation of the basin [11] and containing Plio-Pleistocene sandy deposits with a marine influx. We have sampled in the famous Corinth canal. Finally, the island of Kythira consists of Pre-neogene basement rocks, overlain by a terrigenous clastic succession of presumably Tortonian age, overlain, with an angular unconformity, by an early Pliocene calcareous succession.

\section{Paleomagnetic results}

The detailed paleomagnetic results are listed in Appendices 1 and 2 (ages are indicated) and discussed in their context in the synthesis of the data.

\subsection{Analysis of the natural remanent magnetization (NRM)}

The analysis and interpretation of the natural remanent magnetization followed routine procedures detailed elsewhere [6]. The paleomagnetic results of each region (Appendix 1) are characterized on the basis of several criteria and we distinguish three types of demagnetization behavior.

\subsubsection{Type 1}

The results show a linear decay towards the origin and the present-day field overprint is demonstrably removed (Fig. 2a, b). Some sediments, typically those from Rhodos and some from $\mathrm{Ky}$ thira and the Peloponessos, contain a characteristic remanent magnetization (ChRM) component which is only entirely removed at $680^{\circ} \mathrm{C}$, indicating hematite, but most of the ChRM is removed just below $600^{\circ} \mathrm{C}$ (Fig. 2a), indicating magnetite. Occasionally, the sediments (e.g. Luxurion on Kefallinia, some sites on the Peloponessos, Milos 


\section{Pliocene-Pleistocene}

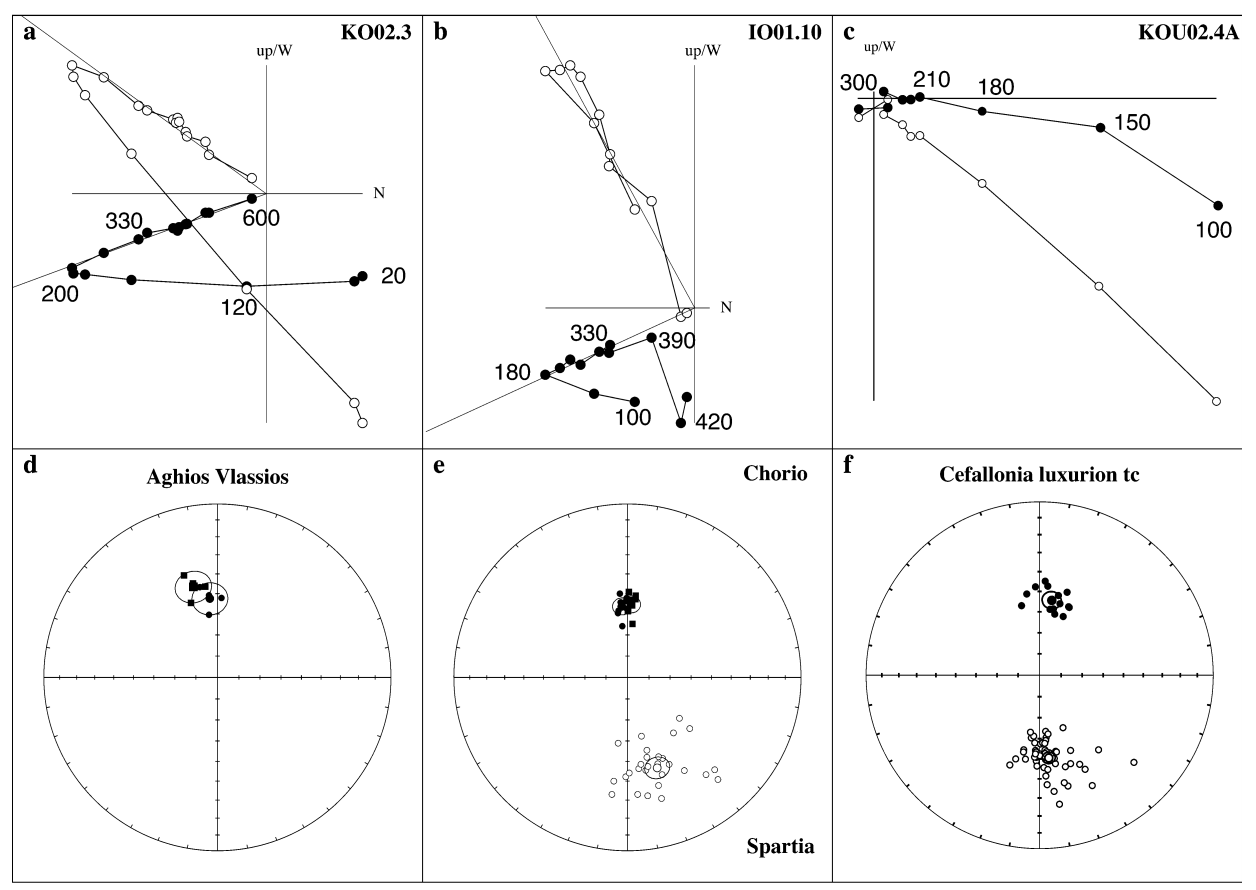

Fig. 2. (a, b, c) Zijderveld diagrams of selected samples after bedding plane correction. Closed (open) circles represent the projection of the NRM vector endpoint on the horizontal (vertical) plane; values indicate temperatures in ${ }^{\circ} \mathrm{C}$. (d, e, f) Equal area projection of ChRM directions and their means; circles are $95 \%\left(\alpha_{95}\right)$ confidence regions; closed (open) symbols refer to normal (reversed) polarity. In (d, e) squares (circles) denote ChRM directions after (before) bedding plane correction.

and Karpathos) contain iron-sulphides as dominant carriers, since the ChRM components are mostly removed at lower temperatures, below $350^{\circ} \mathrm{C}$ (Fig. 2b). These sediments show alteration (oxidation of pyrite) starting at $390^{\circ} \mathrm{C}$, resulting in scatter and random directions at higher temperatures (Fig. 2b). We regard type 1 as reliable and use the results to calculate rotations.

\subsubsection{Type 2}

Sometimes the individual directions per site/section are too dispersed for a statistically significant mean direction, like the results of Spartia Beach (Fig. 2e) and Cape Liakas (on Kefallonia), and the results must be considered with caution. In some sites/sections (on Milos, the Peloponessos, Kythira, Kassos and on Rhodos) not all individual results (of at least seven cores) are reliable and therefore the means are hardly significant, but give merely an indication of the sense of rotation.
Likewise, in rare occasions the inclination is anomalously large or small, and we regard the results as indicative only.

\subsubsection{Type 3}

'Spider-webs' in the demagnetization diagrams are typically found on Lefkas and in the Miocene limestones on Kassos with low intensities. We also include in type 3 overprinted samples with a large present-day field overprint until 240$270^{\circ} \mathrm{C}$ and containing a cluster or scatter above this temperature (Fig. 2c). In particular, results from Plio/Pleistocene sites on Crete and from some sites on Karpathos and Kassos show a present-day field before bedding tilt correction (Fig. 2d); these sites/sections are considered as overprinted, but this is hard to distinguish from non-rotating if the bedding plane is sub-horizontal (Chorio in Fig. 2e). Type 3 is disregarded from any conclusion. 


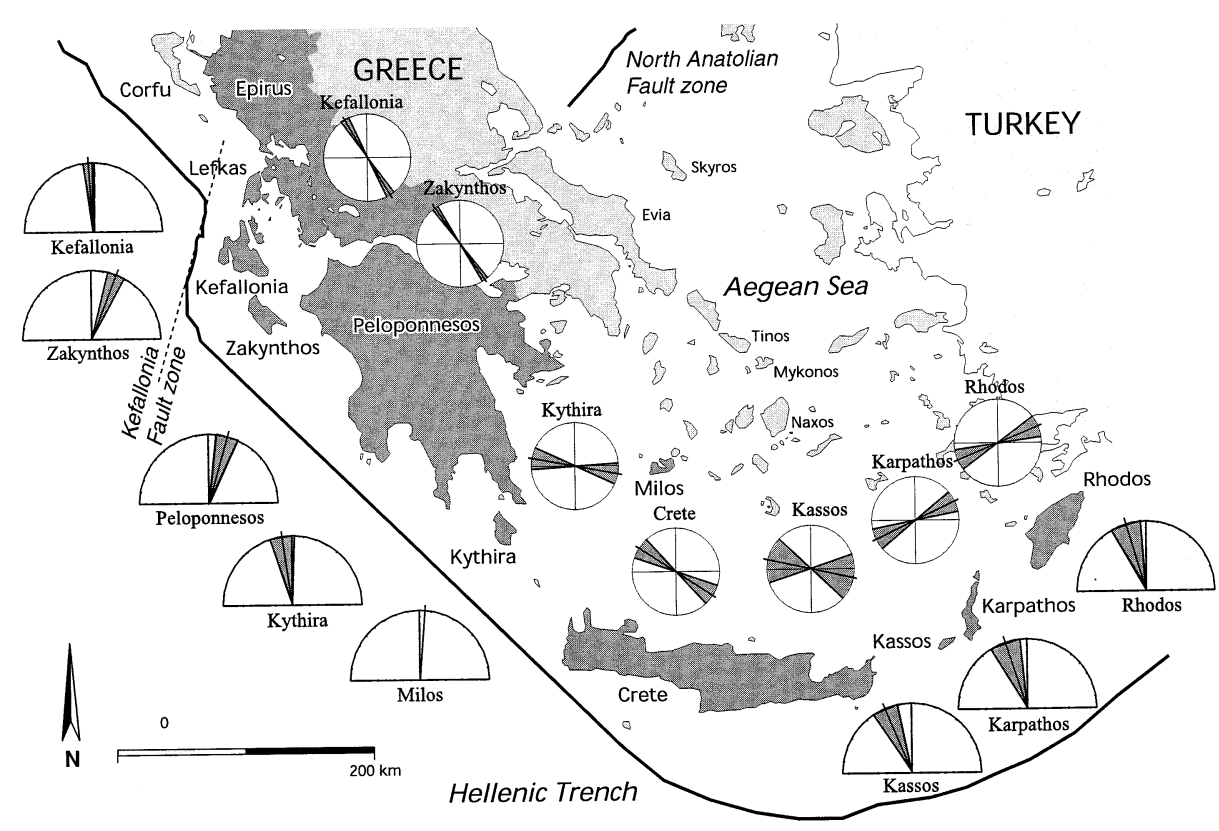

Fig. 3. Distribution of ChRM and AMS data on the Aegean outer-arc. Shaded segment in ChRM plots represents weighted $\alpha_{95}$ $\left(\alpha_{95} / \cos I\right)$ with solid line as mean declination (Appendix 1). Shaded segment in AMS data indicates the $\delta D$ in the AMS analysis with solid line as mean lineation direction per area (Appendix 2).

\subsection{Anisotropy of the magnetic susceptibility}

Analysis of the anisotropy of the magnetic susceptibility (AMS) can be used to establish the sedimentary and tectonic history in weakly deformed sediments, because of the relationship with the regional stress field. In undeformed, fine-grained sediments, the magnetic susceptibility is dominated by foliation coinciding with the bedding plane (i.e. the minimum axes of AMS, $k_{\min }$, are perpendicular to the bedding plane) and a random orientation of the lineation (i.e. direction of the maximum axes of AMS, $k_{\max }$ ). Upon deformation, the lineation quickly aligns along the direction of maximum extension or, equivalently, perpendicular to maximum compression.

The Miocene to Pleistocene sediments from the western Aegean arc and Crete, show NW-SE alignments of the $k_{\max }$ axes, indicating NW-SE extension or NE-SW compression (Appendix 2 and Fig. 3). In the eastern Aegean arc (Rhodos and Karpathos), the Plio/Pleistocene sediments reveal a roughly NE-SW alignment of the $k_{\max }$ axes, implying NE-SW extension or NW-SE compression (Fig. 3). The Miocene sediments on Kassos indicate an approximately E-W clustering of the $k_{\max }$ axes, but with a large error. The clustering of the $k_{\max }$ axes from Plio/Pleistocene sediments on the Peloponessos are not consistent over the peninsula, and therefore cannot be averaged. Likewise, the AMS of the sediments on Milos shows no clear indication of alignments.

\section{Synthesis of data}

Many paleomagnetic key investigations have been carried out by Kissel and Laj ([2] and references therein), aided by structural work [12-14]. They have extensively sampled the Neogene in Greece, visited most of the Aegean outer-arc islands and were the first to propose a kinematic time-constrained reconstruction of the Aegean area. As new techniques developed and more precise time-constraints can be given to Neogene marine sediments on the basis of cyclo/biostratigra- 
phy, a new study of the sediments in the Aegean outer-arc is warranted. Our paleomagnetic results of Miocene to Pleistocene sediments are often compatible with the earlier results, but our new data contribute to a more detailed and significantly different picture of the geodynamics in the Aegean region (Fig. 3).

\subsection{Ionian islands}

Based on paleomagnetic data from Corfu (nine mean directions), Kefallonia (four) and Zakynthos (three), Laj et al. [1] suggested that the western Aegean arc underwent a $\sim 25^{\circ}$ clockwise rotation starting at $5 \mathrm{Ma}$, hence with a rate of approximately $5^{\circ} / \mathrm{Myr}$. Since a total $45-50^{\circ}$ clockwise rotation was revealed from Paleocene to Eocene pelagic limestones [15] which appeared to include the entire Oligocene [16], it was concluded that two distinct clockwise rotations must have occurred in the western Aegean arc, one during the early to middle Miocene and one during the last $5 \mathrm{Myr}$. A recent and more detailed study of Zakynthos [6], however, has shown a different history of at least this part of the western Aegean arc. These data indicate no rotation between 8.11 and $0.77 \mathrm{Ma}$, but a $22 \pm 5^{\circ}$ clockwise rotation phase took place between $0.77 \mathrm{Ma}$ and Recent.

The Plio/Pleistocene section of Luxurion [17] along the SW coast of Kefallonia reveals four polarity zones (N-R-N-R). Most samples are reversed and the section covers the Olduvai subchron and the late Matuyama Chron $(\sim 1.9-1.0$ Ma). The reversed samples (56 cores) give a mean declination indicating no rotation, while the mean of the normal samples (14 cores) shows a small clockwise rotation (Fig. 2f). This is equivalent to the results of Laj et al. [1] who used their (three) normal sites to suggest a clockwise rotation. We prefer to calculate the overall mean of the Luxurion section, indicating no significant rotation since $\sim 1.9 \mathrm{Ma}$, because the results of the N-R$\mathrm{N}-\mathrm{R}$ sequence do not consistently support an opposite sense of rotation. The Miocene and Plio/ Pleistocene sediments on SE Kefallonia seem to indicate anticlockwise rotations, but the large scatter precludes any further conclusions. From
Lefkas, no reliable data could be obtained, while data from Corfu indicate no significant rotation since $\sim 3.5 \mathrm{Ma}$, according to earlier published data [1].

\subsection{Peloponessos}

The Pliocene sediments show clockwise rotations, both in the $\mathrm{S}$ (Kefalas, Gythion) which agrees with earlier results [1], and in the NW (Pyrgos basin [10]). The youngest (probably Pleistocene) sediments in the NW (Pineos), show no rotation. Also the Megalopolis basin (central Peloponessos) and the Megara/Corinth basin (NE Peloponessos) contain Pleistocene sediments covering the Brunhes-Matuyama boundary (0.9 $0.4 \mathrm{Ma}$ ) of which the paleomagnetic results of the Brunhes indicate no rotation. This suggests that (most of) the Peloponessos underwent a young, Pleistocene clockwise rotation phase, possibly in agreement with the results derived from Zakynthos, although age control is less precise.

\subsection{Central Aegean}

On Crete, upper Tortonian to lower Messinian paleomagnetic results show varying but predominantly anticlockwise rotations [5]. Rotations are therefore of post early Messinian age and presumably governed by (local) rotations of faultbounded blocks. To better constrain the age of the anticlockwise rotations, we sampled Plio/Pleistocene sediments in the Heraklion basin (central Crete). Unfortunately, almost all samples were either overprinted, or the bedding plane was subhorizontal and no bedding correction could be applied, necessary for validating a stable ChRM. Thus, although the Plio/Pleistocene sediments show no rotation, this may equally be an artefact. One site (Chersonissos) shows a large anticlockwise rotation, but biostratigraphy reveals a Miocene age which agrees well with the post early Messinian rotations. Overall, the results on Crete do not allow us to date the rotations better than post early Messinian [5]. The Miocene and Pliocene results from Kythira reveal anticlockwise rotations, but the error is large and therefore this result may only be considered as indicative. 
Recent paleomagnetic studies of the inner arc of the Aegean region [3,4] have shown that this area consists of two major blocks having an opposite sense of rotation. The islands of Mykonos and Tinos indicate post middle Miocene clockwise rotations, and Naxos and Milos [18] anticlockwise rotations. The clockwise rotations are consistent with rotations further to the northwest in Evia and Skyros [19], suggesting that the clockwise domain extends as far as Mykonos [3] and that the boundary between the two opposite rotating blocks lies north of Naxos. We note that our results from Milos are not consistent with those from literature, since they show both clockwise and anticlockwise rotations, from different parts of the island possibly reflecting local rotations only.

\subsection{Southeastern Aegean}

Le Pichon and Angelier [12] have suggested a model in which the eastern Aegean arc would have been rotating anticlockwise. This idea was supported by a preliminary study of Laj et al. [20], suggesting a $\sim 23^{\circ}$ anticlockwise rotation on Rhodos. However, a later study by the same group [1] of five sites from middle and upper Pliocene sediments from Rhodos indicated no significant rotation. Our new Plio/Pleistocene data of 13 sites from Rhodos confirm the earlier results since we find only anticlockwise rotations for all sites, having an average rotation of $18 \pm 12^{\circ}$. In addition, the paleomagnetic results from Karpathos and Kassos imply anticlockwise rotations as well. Furthermore, results from Bey Daglari in southern Turkey [21] suggest a $\sim 30^{\circ}$ anticlockwise rotation since $15 \mathrm{Ma}$. This seems to denote an eastern arc area of anticlockwise rotations from Kassos to southern Turkey. The anticlockwise rotations are measured in the youngest (Plio/ Pleistocene) sediments from Karpathos and Rhodos, implying that this rotation phase took place some time during the Pleistocene, but the fossil content of the sediments does not allow a more precise age estimate.

On both sides of the Aegean arc, our new paleomagnetic results indicate a young rotation phase. In the western arc (Zakynthos and the Pelopones- sos), this rotation was clockwise and in the eastern arc (Kassos, Karpathos and Rhodos) anticlockwise both occurring during the Pleistocene, i.e. at least younger than $\sim 1.8 \mathrm{Ma}$ [22].

\section{Block rotations inferred from geodetic data}

The young age of the paleomagnetically observed rotations raises the question whether these rotations can also be observed in the present-day pattern of crustal deformation derived from active crustal motion monitored by satellite geodesy through global positioning systems (GPS). The results of more than 30 occupations of several local networks (see [23]) and of the reoccupation by GPS of a 100 year old triangulation network in central Greece [24] are now combined into one data set of about 240 velocity vectors [25]. This data set is one of the subjects of GPS Seismic hazard IN Greece (SING) project [26]; it covers the entire Aegean region and is densest in central Greece and the Peloponessos. Coseismic effects are removed from the data. The influence of the $M_{\mathrm{s}}=6.2$, June 15, 1995 Egion earthquake (Gulf of Corinth) is subtracted [27] and only measurements made during four campaigns in the Grevena area (northern Greece) after the $M_{\mathrm{s}}=6.6$, May 13, 1995 earthquake are included [25]. Furthermore, the orientation of the 100 year triangulation GPS velocity estimates is constrained using 14 sites common to both the triangulation and the local GPS networks. The results show a high compatibility between short-term and 100 year deformation estimates [25]. We removed those sites that have been measured only twice. The remaining set of 174 vectors is shown in Fig. 4, left panel.

We assume that crustal deformation encompasses slip along faults and continuous deformation in crustal blocks bounded by the faults. We apply the purely kinematic inversion technique developed by Spakman and Nyst [28] to invert the velocity field into joint estimates of strain rates, rotation rates, and fault slip. Fault motion is parameterized as step functions on 10 to 200 $\mathrm{km}$ long great circle fault segments, and continuous deformation as general linear strain and rota- 

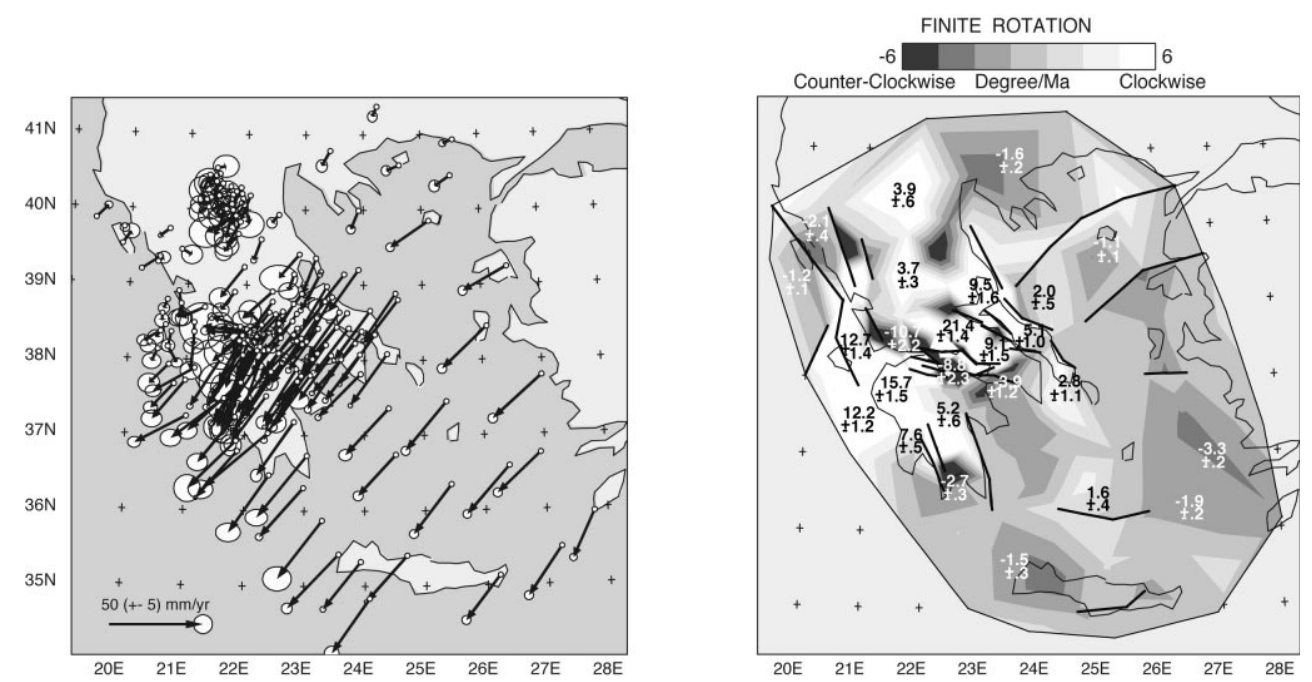

Fig. 4. Left panel: The velocity vectors with their $3 \sigma$ errors ellipses from a combination of several GPS campaigns [25] defined with respect to a reference frame fixed to Eurasia. Right panel: Contoured geodetic rotation rates scaled to degrees per Myr. The numbers refer to local $(50-100 \mathrm{~km}$ scale) averages of rotation rates with $3 \sigma$ errors.

tion rate behavior between model nodes defined by a triangulation of crustal blocks. The inversion results are slip vectors on fault segments and the four elements of the velocity gradient tensor at each model node. We restricted the fault parameterization to the largest and most active faults, implying that continuous deformation can in part be due to slip on non-parameterized faults. We apply the regional fault parameterization of Jolivet et al. [29], with a more detailed parameterization of the Gulf of Corinth [30]. For the inversion, we use the relative velocity differences between every pair of stations.

The solution shows relatively small fault movements, but the the inclusion of fault motion has significant influence. Since continuous deformation can vary discontinuously across fault traces, anomalously high deformation rates, especially in the Gulf of Corinth, are avoided. Here, we are mainly concerned with the rotation rates (the antisymmetric part of the velocity gradient tensor), presented as finite angles of rotation about vertical axes (Fig. 4, right panel); the results will be discussed below.

\section{Discussion}

\subsection{Coincident tectonic events during the early Pleistocene}

The onset of the inferred young rotation phase shows a remarkable coincidence with other tectonic changes in the Aegean. It is generally believed that a change in stress regime between 0.8 and $0.3 \mathrm{Ma}$ affected the Aegean region [14,31]. NE-SW tensional stress in central and northern Greece to N-S tension in Turkey prevailed in the early Pliocene-Early Pleistocene. This changed in the middle Pleistocene-Recent to NNW-SSE tensional stress in central and northern Greece, and towards NE-SW tension in western Turkey. Possibly, the two phases of extension were separated by a short period of dominant compression $[14,31]$. Around the same time, a rapid phase of rifting opened the Gulf of Corinth [30]. The major normal fault bounding the Megara basin (NE Peloponessos) was initiated at a similar age of $0.9 \pm 0.2 \mathrm{Ma}$ (Collier, personal communication, 1999). The change of stress regime was accompanied by uplift of the entire Aegean outer-arc, in accordance with much of the relief of southern Greece having been developed during the last million years [32]. All these results imply that the 
tectonic regime of the Aegean outer-arc changed drastically around $1 \mathrm{Ma}$.

\subsection{AMS results}

The AMS data derived from the sediments of the Aegean arc clearly show extension parallel, or compression perpendicular to the Aegean arc (Fig. 3), in agreement with similar AMS data from the Ionian islands [33]. Geodetic data [34], earthquake focal mechanisms [35], microseismics [36] and faults observed in the field [37] suggest arc-parallel extension for the region between the volcanic arc and the outer-arc in the southern Aegean, whereas earthquake focal mechanisms [38] and field data [39] imply a prevalence of arc-normal compression in the NW Aegean arc. Our AMS data are consistent with the other types of observations and provides independent support for the inferred pattern of strain.

\subsection{Comparison with active crustal rotation rates}

Our new paleomagnetic data modify the tectonic evolution of the outer Aegean arc and indicate a rapid, Pleistocene phase of rotation; tectonic rotations prior to this young phase are not well constrained. The results are consistent with the crustal rotations derived from the geodetic data which reveal clockwise rotations in the mainland of Greece and (small) anticlockwise rotations in the (south)-eastern Aegean. A narrow band of strong anticlockwise rotations is located along the Gulf of Corinth, probably related to the complicated fault structure in this area. We find significant clockwise rotations of Lefkas, Kefallonia and Zakynthos, and in the western and central Peloponessos.

In comparing the geodetic and paleomagnetic results, care should be taken for two reasons. Geodetic rotation rates are representative for the period of observation (e.g. approximately 100 years), hence any comparison must rely on the assumption that the present-day pattern is representative for the past $0.8 \mathrm{Myr}$. Furthermore, computed rates refer to rotation around a vertical axis of a small rigid equidimensional element, while paleomagnetic rotations may represent considerable blocks. Nevertheless, we find large parts of the Aegean rotating in the same manner. In particular, a mode of clockwise rotations on the Peleponessos agrees with the results of Le Pichon et al. [39].

\subsection{Geodynamic models compared with paleomagnetic data}

The young rotation phase of the eastern arc and the revised timing and rate of rotation of the western arc form new constraints on the mechanism of Aegean deformation. It would appear that at around $0.8 \mathrm{Ma}$ an important change

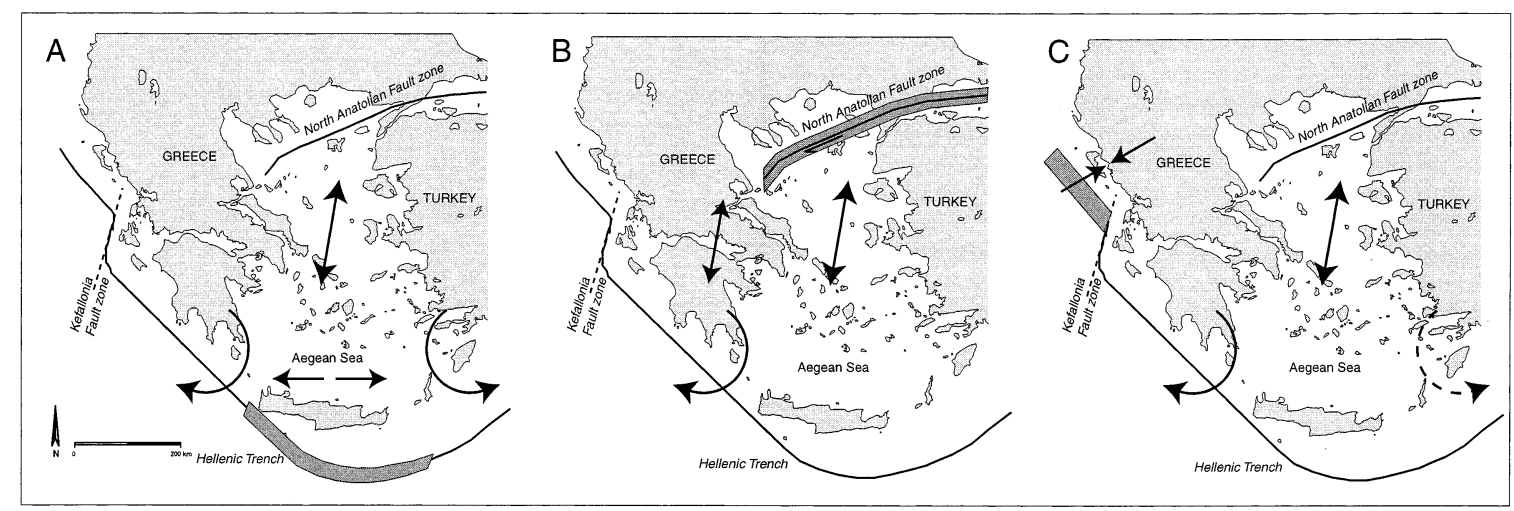

Fig. 5. Tectonic models for the Aegean as discussed in the text. A: Model based on increase in resistance at the central segment of the subduction zone [35,37,40]. B: Model involving a change of activity of the North Anatolian fault [30]. C: Model involving lateral migration of slab detachment [43]. 
occurred in the distribution of forces acting on the region. We will evaluate three previously proposed models for the tectonic evolution, in the light of our new observations.

A first scenario explains the prevalence of arcparallel extension in the southern Hellenic arc to be caused by an increase in resistance at the central segment of the subduction zone, following, perhaps, incipient collision with the African continental lithosphere $[35,37,40]$. From a geometrical point of view, such a blocking of southward motion could be associated with clockwise rotation of the western arc and anticlockwise rotation of the eastern arc segment (Fig. 5A). However, the arc-parallel extension is estimated to have started significantly earlier than $0.8 \mathrm{Ma}$, and was dated at about 2-4 Ma [37] and 3-6 Ma [40]. The role of resistance, however, might be small since the outermost accretionary arc sediments are probably still unconsolidated and may oppose little resistance to deformation (Muttoni, personal communication, 1999).

A second scenario involves an essential role of the westward moving Anatolian plate. Armijo et al. [30] argue that the onset of rapid extension across the Gulf of Corinth reflects the westward propagation of the North Anatolian fault system (Fig. 5B). The geometry of extension would cause the Peloponessos to rotate clockwise relative to the area north of the Gulf, a configuration which could at least partly explain our new observations. Temporal changes in the North Anatolian fault system have also been suggested to explain the Pleistocene change in the pattern of extension [41].

A third scenario entails changes in deformation around $0.8 \mathrm{Ma}$ to reflect a change in the nature of the plate boundary of northwestern Greece (Fig. 5C). At present, subduction of African lithosphere below the SW moving Aegean overriding margin terminates in the region of the Ionian islands. West of Epirus, the two plates collide and convergence is largely blocked. Geodesy indicates the transition to be localized in a narrow zone (Fig. 4) of which the Kefallonia fault zone is the most important discontinuity (Fig. 5). Geometrically, we expect the transition from subduction to collision to be associated with clockwise rotation of the western Hellenic arc (Fig. 5). This is confirmed by the rotation pattern computed from geodesy and by the results of numerical modelling [41]. Numerical modelling also suggests that a change in the nature of the margin of northwestern Greece can also account for the Pleistocene change in the pattern of extension [42]. A change in collisional state can result from the southeastward propagation of a horizontal tear in the subducted African lithosphere below the western margin, as derived from tomography $[43,44]$. Slab detachment will locally stop the roll back of the subduction zone since the weight of the slab is no longer transmitted to the surface portion of the plate. If indeed a transition from subduction to collision causes clockwise rotation, we may speculate that also the rapid Pleistocene rotation of the western arc is caused by lateral migration of slab detachment, while at the same time offering a possible mechanism for the Pleistocene uplift of the Hellenic arc through a rebound process following detachment [43]. Van der Meulen et al. [45] argue for such a mechanism along the Adriatic peninsula based on an analysis of vertical movements. Moreover, increased slab pull at the still continuous segment of the subduction zone is likely to increase roll back. The increase may be considerable considering the old and dense Ionian oceanic crust. Detachment would thereby affect the Hellenic arc along its full width, but whether this could also induce (anticlockwise) rotations on the eastern arc segment must at present remain speculative.

\section{Conclusions}

Our paleomagnetic data show that the western Aegean arc underwent a clockwise rotation phase, whereas the eastern arc experienced anticlockwise rotations. Furthermore, the results from the western arc indicate that the clockwise rotation phase took place between $\sim 0.8 \mathrm{Ma}$ and Recent on $\mathrm{Za}$ kynthos and at least $<1.8 \mathrm{Ma}$ on the Peloponessos. The anticlockwise rotation phase in the south-eastern arc may be equally young $(<1.8$ $\mathrm{Ma})$, although dating is insufficiently accurate. The current pattern of rotations appears to match 
the interpreted geodetic data, which indicate (considerable) clockwise rotations in the western Aegean arc and (small) anticlockwise rotations in the eastern Aegean arc. Our AMS data agree with arc-parallel extension in the $\mathrm{S}$ and SE Aegean arc, and arc-normal compression in the NW part, as derived from geologic and geodetic data. At the time of our rotation phase, the Aegean area was subject to major uplift and a major change in overall stress regime.

\section{Acknowledgements}

We thank Johan Meulenkamp, Wout Krijgsman, Davide Duranti, Erik Snel and Nicole van Vugt for their discussions and/or help in the field. Nicole van Vugt provided unpublished data from Rhodos (Appolakkia), Milos (HOT) and the Peloponessos (Megalopolis). Geert Ittmann analyzed the nannoplankton. Comments by Rinus Wortel and the reviews of Giovanni Muttoni and Hans-Gert Kahle greatly improved the manuscript. We thank Peter Clarke for discussions and for providing the vector data of the SING project. The Kanaris family of the Amalia Hotel in Apolakkia (Rhodos) is thanked for their hospitality. The I.G.M.E. and the archeological survey of Rhodos provided the necessary working permits. This work was conducted under the programme of the Vening Meinesz research School of Geodynamics (VMSG).[R $\boldsymbol{V}]$

\section{Appendix 1}

Results from NRM analysis from the different sections/sites along the Aegean outer-arc (for sample codes, see Fig. 1); (no) tc $=$ (un)corrected for bedding tilt, ages are indicated. $N=$ number of specimens; $D, I=$ site mean ChRM declination and inclination; $k=$ Fisher's precision parameter; $\alpha_{95}=95 \%$ cone of confidence. Type 1 indicates reliable results, Type 2 gives an indication of the sense of rotation, and Type 3 is unreliable. N (R) represents normal (reversed) polarity, rot $=$ rotation with (a)c indicating (anti)clockwise. For details on ChRM data from Zakynthos, we refer to [6]. Asterisk (*) marks the data used to calculate the mean of an area.

Biostratigraphy [22,46-48]; a presence of large Gephyrocapsa spp., H. balthica and H. selli, absence of C. Macintyrei and Gephyrocapsa sp. $3=\mathrm{NN} 19 \mathrm{~d}$ [17], 1.22-1.373 Ma; ${ }^{\mathrm{b}}$ relative ages after Hageman [10]; ${ }^{\mathrm{c}} G$. bononiensis [7], 2.41$3.31 \mathrm{Ma} ;{ }^{\mathrm{d}} G$. margaritae and $D$. assymetricus [7], 3.81-4.12 Ma; ${ }^{\mathrm{e}} \mathrm{H}$. selli and small Gephyrocap$s a$, no oceanica, until $1.71 \mathrm{Ma} ;{ }^{\mathrm{f}} P$. lacunosa, $R$. pseudoumbulica, D. tamalis, H. selli, D. aymetricus, small Gephyrocapsa, D. Brouweri, no oceanica (this study), 4.91-0.44 Ma; ${ }^{\mathrm{g}} P$. lacunosa (this study), until $0.44 \mathrm{Ma} ;{ }^{\mathrm{h}} G$. ruber and $G$. inflata [49], from $2.09 \mathrm{Ma} ;{ }^{\mathrm{i}}$ Gephyrocapsa oceanica, small Gephyrocapsa, P. lacunosa (this study), until 0.44 $\mathrm{Ma} ;{ }^{\mathrm{j}}$ Gephyrocapsa oceanica, small Gephyrocapsa, P. lacunosa, $12 \mathrm{~m}$ Macintyrei (this study), until 1.67 Ma; other ages are derived from the Geological map of Greece. 


\begin{tabular}{|c|c|c|c|c|c|c|c|c|c|c|c|c|c|c|}
\hline Locality & Code & $N$ & $\begin{array}{l}D_{\text {no tc }} \\
\left({ }^{\circ}\right)\end{array}$ & $\begin{array}{l}I_{\text {no tc }} \\
\left({ }^{\circ}\right)\end{array}$ & $k$ & $\begin{array}{l}\alpha_{95} \\
\left(^{\circ}\right)\end{array}$ & Type & $\begin{array}{l}D_{\mathrm{tc}} \\
\left({ }^{\circ}\right)\end{array}$ & $\begin{array}{l}I_{\mathrm{tc}} \\
\left({ }^{\circ}\right)\end{array}$ & $k$ & $\begin{array}{l}\alpha_{95} \\
\left({ }^{\circ}\right)\end{array}$ & Polarity & Rot & Age (Ma) \\
\hline \multicolumn{15}{|l|}{ Lefkas } \\
\hline Komilio & KOM & 4 & - & - & - & - & 3 & - & - & - & - & $\mathrm{N}$ & - & $\begin{array}{l}\text { Mid-Upper } \\
\text { Pliocene }\end{array}$ \\
\hline Alatron & ALA & 6 & - & - & - & - & 3 & - & - & - & - & $\mathrm{N}$ & - & $\begin{array}{l}\text { Burdigalian-- } \\
\text { Langhian }\end{array}$ \\
\hline Kolivata & KOL & 4 & - & - & - & - & 3 & - & - & - & - & $\mathrm{N}$ & - & Langhian \\
\hline \multicolumn{15}{|l|}{ Kefallonia } \\
\hline LUXmean ${ }^{a}$ & & 70 & 159.0 & -49.1 & 40.1 & 2.7 & 1 & 176.6 & -51.2 & 45.1 & 2.6 & $\mathrm{~N} / \mathrm{R}$ & $3 \mathrm{ac}$ & $\sim 1.9-1.0$ \\
\hline Luxurion & LUX & 14 & 346.4 & 57.7 & 52.2 & 5.6 & 1 & 9.2 & 53.9 & 88.6 & 4.2 & $\mathrm{~N}$ & $9 \mathrm{c}$ & Plio/Pleistocene \\
\hline Luxurion & LUX & 56 & 157.5 & -46.9 & 44.8 & 2.9 & 1 & 173.7 & -50.4 & 45.4 & 2.9 & $\mathrm{R}$ & $6 \mathrm{ac}$ & Plio/Pleistocene \\
\hline Spartia & SPA & 28 & 129.8 & -41.3 & 11.3 & 13.5 & 2 & 161.7 & -44.0 & 26.0 & 5.5 & $\mathrm{R}$ & - & Plio/Pleistocene \\
\hline Liakas & LIA & 12 & 153.9 & -45.6 & 26.0 & 5.5 & 2 & 168.3 & -38.2 & 17.0 & 10.8 & $\mathrm{~N} / \mathrm{R}$ & - & Messinian \\
\hline \multicolumn{15}{|l|}{ Zakynthos } \\
\hline mean & & 8 & - & - & - & - & 1 & 21.6 & 48.8 & 128.0 & 4.9 & $\mathrm{~N} / \mathrm{R}$ & $22 \mathrm{c}$ & $8.11-0.77$ \\
\hline \multicolumn{15}{|l|}{ Peloponessos } \\
\hline mean & & 4 & - & - & - & - & 1 & 16.1 & 55.2 & 325.6 & 5.1 & $\mathrm{~N} / \mathrm{R}$ & $16 \mathrm{c}$ & Pliocene \\
\hline \multicolumn{15}{|l|}{$\underline{\text { Pyrgos Basin }}^{\text {b }}$} \\
\hline Aghios Andreas & AA & 5 & 25.2 & 51.7 & 35.8 & 13.0 & 2 & 14.0 & 55.5 & 36.4 & 12.8 & $\mathrm{~N}$ & - & Plio/Pleistocene \\
\hline Killini* & KIL & 11 & 183.50 & -70.9 & 58.1 & 6.0 & 1 & 205.4 & -57.0 & 53.7 & 6.3 & $\mathrm{~N} / \mathrm{R} / \mathrm{N}$ & $25 \mathrm{c}$ & Plio/Pleistocene \\
\hline Pineos & PIN & 7 & 356.1 & 57.2 & 43.0 & 9.3 & 2 & 357.4 & 65.2 & 43.0 & 9.3 & $\mathrm{~N}$ & - & Pleistocene \\
\hline Erymanthos & ERI & 6 & 194.4 & -54.9 & 97.4 & 6.8 & 2 & 195.8 & -43.3 & 96.4 & 6.9 & $\mathrm{R} / \mathrm{N}$ & - & Pliocene \\
\hline Neraida & NER & 5 & 211.9 & -46.6 & 37.9 & 12.6 & 2 & 207.6 & -48.6 & 37.9 & 12.6 & $\mathrm{R}$ & & Pliocene \\
\hline Krionero* & KRI & 14 & 14.8 & 55.2 & 87.0 & 4.3 & 1 & 10.7 & 53.5 & 87.0 & 4.3 & $\mathrm{~N}$ & $11 \mathrm{c}$ & Pliocene \\
\hline Vounargon & VOU & 5 & 201.9 & -55.1 & 59.3 & 10.0 & 2 & 194.0 & -50.5 & 54.7 & 10.4 & $\mathrm{R}$ & - & Pliocene \\
\hline Alfioussa & ALF & 6 & 185.0 & -27.0 & 14.2 & 18.4 & 2 & 184.7 & -44.2 & 14.3 & 18.3 & $\mathrm{R}$ & - & Pliocene \\
\hline Lalas & LAL & 6 & 2.6 & 48.7 & 147.2 & 5.5 & 2 & 358.7 & 51.4 & 197.1 & 4.8 & $\mathrm{~N}$ & - & Pliocene \\
\hline Kalithea & KAL & 4 & 161.8 & -62.6 & 476.0 & 4.2 & 2 & 186.6 & -52.4 & 475.9 & 4.2 & $\mathrm{R}$ & - & Pliocene \\
\hline Grillos & GRI & 3 & 346.5 & 40.4 & 345.7 & 6.6 & 2 & 357.7 & 41.1 & 345.7 & 6.6 & $\mathrm{~N}$ & - & Upper Pliocene \\
\hline Chrysophylli* & CHR & 15 & 21.9 & 40.2 & 64.2 & 4.8 & 1 & 12.1 & 57.4 & 42.4 & 5.9 & $\mathrm{~N}$ & $12 \mathrm{c}$ & Pliocene \\
\hline \multicolumn{15}{|l|}{ South: } \\
\hline Kefalas* & $\mathrm{KEF}$ & 11 & 13.0 & 52.3 & 89.1 & 4.9 & 1 & 16.5 & 52.4 & 154.0 & 3.7 & $\mathrm{~N}$ & $17 \mathrm{c}$ & Upper Pliocene \\
\hline Gythion & GIT & 2 & 7.7 & 41.6 & 0.0 & 99.9 & 2 & 8.0 & 48.6 & - & - & $\mathrm{N}$ & - & Upper Pliocene \\
\hline Glikovrisi & GVR & 2 & 186.2 & -48.0 & 0.0 & 99.9 & 2 & 180.0 & -50.8 & - & - & $\mathrm{R}$ & - & Upper Pliocene \\
\hline \multicolumn{15}{|l|}{ Peloponessos } \\
\hline \multicolumn{15}{|l|}{ East: } \\
\hline Megara & MEG & 12 & 3.1 & 48.9 & 20.5 & 9.8 & 1 & 2.7 & 46.7 & 35.5 & 7.4 & $\mathrm{~N} / \mathrm{R} / \mathrm{N} / \mathrm{R} / \mathrm{N}$ & $3 \mathrm{c}$ & Plio/Pleistocene \\
\hline Corinth & COR & 5 & 177.4 & -57.9 & 26.3 & 15.2 & 2 & 177.4 & -57.9 & 26.3 & 15.2 & $\mathrm{R} / \mathrm{N}$ & - & Pleistocene \\
\hline \multicolumn{15}{|l|}{ Centre: } \\
\hline Megalopolis & ME & 71 & 2.6 & 53.8 & 58.1 & 2.2 & 1 & 1.2 & 52.6 & 52.0 & 2.4 & $\mathrm{R} / \mathrm{N}$ & $1 \mathrm{c}$ & $0.9-0.4$ \\
\hline \multicolumn{15}{|l|}{ Milos } \\
\hline mean & & 2 & - & - & - & - & 1 & 184.5 & -51.8 & - & - & & $5 \mathrm{c}$ & \\
\hline Basalt & MYL 1 & 7 & 171.6 & -24.2 & 43.4 & 9.3 & 2 & 171.6 & -24.2 & 43.4 & 9.3 & $\mathrm{R}$ & - & Pliocene \\
\hline Myl10 & MYL 10 & 5 & 12.5 & 46.3 & 73.6 & 9.0 & 2 & 11.2 & 51.2 & 73.6 & 9.0 & $\mathrm{~N}$ & - & Plio/Pleistocene \\
\hline Myl11 & MYL 11 & 5 & 357.7 & 52.0 & 359.1 & 4.0 & 2 & 354.4 & 56.4 & 359.1 & 4.0 & $\mathrm{~N}$ & - & Plio/Pleistocene \\
\hline Myl15* & MYL 15 & 7 & 347.2 & 54.3 & 66.8 & 7.4 & 1 & 348.9 & 57.1 & 66.8 & 7.4 & $\mathrm{~N}$ & $11 \mathrm{ac}$ & Plio/Pleistocene \\
\hline Hot* & HOT & 11 & 185.3 & -48.9 & 114.7 & 4.3 & 1 & 192.0 & -35.8 & 114.7 & 4.3 & N/R/N/R & $12 \mathrm{c}$ & Early Pliocene \\
\hline \multicolumn{15}{|l|}{ Kythira } \\
\hline Avlemonas & $\mathrm{AV}$ & 8 & 345.9 & 56.6 & 39.2 & 9.0 & 2 & 341.1 & 63.7 & 43.5 & 8.5 & $\mathrm{~N}$ & - & Middle Pliocene \\
\hline Kapsali & KAP & 12 & 13.1 & 49.8 & 29.2 & 8.2 & 1 & 351.9 & 39.4 & 29.7 & 8.1 & $\mathrm{~N}$ & 8 ac & Miocene \\
\hline Manitochori & MAN & 6 & 355.2 & 49.2 & 20.2 & 15.3 & 2 & 353.4 & 47.1 & 16.8 & 16.8 & $\mathrm{~N}$ & - & Miocene \\
\hline \multicolumn{15}{|l|}{ Crete } \\
\hline Fortetsa $^{c}$ & FOR & 7 & 1.1 & 41.4 & 76.4 & 6.9 & 3 & 1.1 & 41.4 & 76.4 & 6.9 & $\mathrm{~N}$ & - & Pliocene \\
\hline Vasileis & VAS & 7 & 356.4 & 54.9 & 161.1 & 4.8 & 3 & 354.4 & 46.5 & 161.1 & 4.8 & $\mathrm{~N}$ & - & Pliocene \\
\hline Prassas & PRA & 8 & 358.5 & 51.2 & 87.6 & 6.0 & 3 or no rot & 3.0 & 45.7 & 153.8 & 4.5 & $\mathrm{~N}$ & - & Mio/Pliocene \\
\hline
\end{tabular}




\begin{tabular}{|c|c|c|c|c|c|c|c|c|c|c|c|c|c|c|}
\hline Locality & Code & $N$ & $\begin{array}{l}D_{\text {no tc }} \\
\left({ }^{\circ}\right)\end{array}$ & $\begin{array}{l}I_{\text {no tc }} \\
\left({ }^{\circ}\right)\end{array}$ & $k$ & $\begin{array}{l}\alpha_{95} \\
\left({ }^{\circ}\right)\end{array}$ & Type & $\begin{array}{l}D_{\mathrm{tc}} \\
\left({ }^{\circ}\right)\end{array}$ & $\begin{array}{l}I_{\mathrm{tc}} \\
\left({ }^{\circ}\right)\end{array}$ & $k$ & $\begin{array}{l}\alpha_{95} \\
\left({ }^{\circ}\right)\end{array}$ & Polarity & Rot & Age (Ma) \\
\hline Gallini & GAL & 2 & 143.9 & -80.4 & 0.0 & 99.9 & 2 & 162.7 & -68.6 & - & - & $\mathrm{R}$ & - & Pleistocene \\
\hline Koutres & $\mathrm{KOU}$ & 7 & 1.7 & 56.5 & 801.4 & 2.1 & 3 or no rot & 357.9 & 51.9 & 60.2 & 7.8 & $\mathrm{~N}$ & - & Pliocene \\
\hline Moria & MOR & 8 & 356.6 & 46.2 & 27.9 & 10.7 & 3 or no rot & 10.9 & 61.5 & 34.4 & 9.6 & $N / R$ & - & Plio/Pleistocene \\
\hline Galipe & LIP & 2 & 180.6 & -52.4 & 0.0 & 99.9 & 2 or no rot & 186.0 & -57.8 & - & - & $\mathrm{R}$ & - & Pliocene \\
\hline Aghios Vlassios $^{\mathrm{d}}$ & VLA & 4 & 354.5 & 52.3 & 134.6 & 7.9 & 3 & 345.1 & 45.0 & 134.6 & 7.9 & $N / R$ & - & Pliocene \\
\hline Moni Agarathou & AGA & 6 & 356.1 & 36.2 & 345.1 & 3.6 & 3 & 358.4 & 38.9 & 345.2 & 3.6 & $\mathrm{~N}$ & - & Pliocene \\
\hline Chorio & $\mathrm{CHO}$ & 7 & 355.4 & 56.2 & 212.7 & 4.1 & 3 or no rot & 2.9 & 55.2 & 212.7 & 4.1 & $\mathrm{~N}$ & - & Pliocene \\
\hline Aghios Miron & MIR & 5 & 356.0 & 42.9 & 418.2 & 3.7 & 3 & 344.7 & 40.2 & 418.2 & 3.7 & $\mathrm{~N}$ & - & Messinian \\
\hline Chersonissos & HER & 8 & 340.0 & 40.5 & 68.0 & 6.8 & 1 & 334.3 & 31.8 & 68.0 & 6.8 & $\mathrm{~N}$ & $26 \mathrm{ac}$ & Miocene \\
\hline \multicolumn{15}{|l|}{ Kassos } \\
\hline Aghios Mamas & MAM & 7 & - & - & - & - & 3 & - & - & - & - & $\mathrm{R} /$ ? & - & Miocene \\
\hline Chelatron 1 & CHE 1 & 5 & 3.2 & 44.9 & 167.0 & 5.9 & 3 & 13.2 & 40.0 & 167.0 & 5.9 & $\mathrm{~N}$ & - & Miocene \\
\hline Chelatron 2 & CHE 2 & 5 & 336.7 & 47.3 & 99.5 & 7.7 & 2 & 337.3 & 48.1 & 99.5 & 7.7 & $\mathrm{~N}$ & $23 \mathrm{ac}$ & Miocene \\
\hline Chelatron 3 & CHE 3 & 5 & 2.5 & 51.8 & 582.7 & 5.1 & 3 & 350.2 & 46.2 & 582.7 & 5.1 & $N / R$ & - & Miocene \\
\hline \multicolumn{15}{|l|}{ Karpathos } \\
\hline Lefkos & LEF & 17 & 354.9 & 55.2 & 102.9 & 3.5 & 3 & 356.2 & 60.9 & 83.7 & 3.9 & $\mathrm{~N}$ & - & Plio/Pleistocene \\
\hline Amoopi ${ }^{\mathrm{e}}$ & $\mathrm{AM}$ & 5 & 354.5 & 49.9 & 524.3 & 3.3 & 3 & 339.6 & 43.9 & 524.3 & 3.3 & $\mathrm{~N}$ & - & Pliocene \\
\hline Aghios Ioannis & IO & 9 & 166.1 & -52.8 & 49.9 & 7.4 & 1 & 162.0 & -55.9 & 48.4 & 7.5 & $\mathrm{R}$ & $18 \mathrm{ac}$ & Pliocene \\
\hline Pigadia $^{\mathrm{f}}$ & PI & 7 & 8.5 & 57.6 & 182.6 & 4.5 & 3 & 340.1 & 69.4 & 182.6 & 4.5 & $\mathrm{~N}$ & - & Pliocene \\
\hline \multicolumn{15}{|l|}{ Rhodos } \\
\hline mean & & 8 & - & - & - & - & 1 & 162.5 & -46.8 & 45.3 & 8.3 & & $18 \mathrm{ac}$ & \\
\hline Ancient Kameiros* & $\mathrm{AK}$ & 19 & 356.9 & 19.7 & 9.5 & 11.5 & 1 & 352.8 & 45.8 & 9.4 & 11.6 & $\mathrm{~N}$ & 7 ac & Pliocene \\
\hline $\mathrm{ASH}^{*}$ & $\mathrm{ASH}$ & 12 & 115.1 & -83.9 & 11.8 & 13.2 & 1 & 152.0 & -36.8 & 8.8 & 15.5 & $\mathrm{R}$ & $28 \mathrm{ac}$ & Oligocene? \\
\hline Falliraki* & FA & 8 & 340.2 & 49.4 & 70.0 & 6.7 & 1 & 348.7 & 48.6 & 70.0 & 6.7 & $\mathrm{~N}$ & $11 \mathrm{ac}$ & Upper Pliocene \\
\hline Falliraki Beach* & $\mathrm{FB}$ & 11 & 326.9 & 60.4 & 37.7 & 7.5 & 1 & 337.7 & 63.0 & 56.8 & 6.1 & $\mathrm{~N}$ & $22 \mathrm{ac}$ & Upper Pliocene \\
\hline Kallithea & KA & 4 & 149.9 & -32.3 & 36.7 & 15.4 & 2 & 157.1 & -36.9 & 36.7 & 15.4 & $\mathrm{R}$ & - & Upper Pliocene \\
\hline Kolimbia*g & KO & 17 & 163.8 & -42.2 & 18.2 & 8.6 & 1 & 165.8 & -42.2 & 18.2 & 8.6 & $\mathrm{R}$ & $14 \mathrm{ac}$ & $\begin{array}{l}\text { Uppermost } \\
\text { Pliocene }\end{array}$ \\
\hline Ladiko*h & LA & 9 & 332.2 & 30.2 & 44.8 & 7.8 & 1 & 335.1 & 29.6 & 44.8 & 7.8 & $\mathrm{~N}$ & $25 \mathrm{ac}$ & Pliocene \\
\hline Pefki Beach*i & $\mathrm{PB}$ & 12 & 184.9 & -45.5 & 42.7 & 6.7 & 1 & 173.0 & -49.8 & 42.6 & 6.7 & $\mathrm{R} / \mathrm{N}$ & $7 \mathrm{ac}$ & $\begin{array}{l}\text { Upper Pliocene/ } \\
\text { Pleistocene }\end{array}$ \\
\hline Pylonas ${ }^{j}$ & PY & 6 & 163.5 & -37.5 & 21.4 & 14.8 & 2 & 160.2 & -42.3 & 21.4 & 14.8 & $\mathrm{R} / \mathrm{N}$ & - & $\begin{array}{l}\text { Uppermost } \\
\text { Pliocene }\end{array}$ \\
\hline Skaloniti & SK & 5 & 176.8 & -30.5 & 324.2 & 4.3 & 2 & 168.9 & -51.0 & 324.2 & 4.3 & $\mathrm{R}$ & - & Pliocene \\
\hline Tsambika & TS & 5 & 167.9 & -41.1 & 11.7 & 23.4 & 2 & 168.7 & -42.4 & 11.7 & 23.4 & $N / R$ & - & Pliocene \\
\hline Vagies & VA & 4 & 348.0 & 38.4 & 26.1 & 18.3 & 2 & 351.2 & 18.8 & 26.1 & 18.3 & $\mathrm{~N}$ & - & Upper Pliocene \\
\hline Appolakkia* & AGI & 17 & 35.7 & 58.1 & 35.3 & 6.1 & 1 & 335.8 & 56.1 & 35.3 & 6.1 & $\mathrm{~N}$ & $24 \mathrm{ac}$ & Pliocene \\
\hline
\end{tabular}

\section{Appendix 2}

Results from AMS analysis from the different sections/sites along the Aegean outer-arc, corrected for bedding tilt; ages are indicated. $N=$ number of specimens; $D, I=$ mean azimuth and dip of $k_{\max }$ axes; $\delta D, \delta I=$ errors in mean $k_{\max }$ axes; $L=$ magnetic lineation $\left(k_{\max } / k_{\text {int }}\right)$. For location of AMS data from Zakynthos, we refer to [6]. Asterisk $\left(^{*}\right)$ marks not enough data to perform a Hotelling's $T$ anisotropy test [50]. 


\begin{tabular}{|c|c|c|c|c|c|c|c|}
\hline Locality & $N$ & $\begin{array}{l}D \\
\left({ }^{\circ}\right)\end{array}$ & $\begin{array}{l}I \\
\left({ }^{\circ}\right)\end{array}$ & $\begin{array}{l}\delta D \\
\left({ }^{\circ}\right)\end{array}$ & $\begin{array}{l}\delta I \\
\left({ }^{\circ}\right)\end{array}$ & $L$ & $\begin{array}{l}\text { Age } \\
(\mathrm{Ma})\end{array}$ \\
\hline \multicolumn{8}{|l|}{ Lefkas } \\
\hline Komilio & & - & - & - & - & - & Mid-Upper Pliocene \\
\hline Alatron & & - & - & - & - & - & Burdigalian-Langhian \\
\hline Kolivata & & - & - & - & - & - & Langhian \\
\hline \multicolumn{8}{|l|}{ Kefallonia } \\
\hline mean & 149 & 149.3 & 0.6 & 5.7 & 1.3 & 1.0063 & $\sim 1.9-1.0$ \\
\hline Luxurion & 95 & 158.9 & 1.3 & 4.7 & 1.4 & 1.0077 & Plio/Pleistocene \\
\hline Spartia & 31 & 309.4 & 2.1 & 4.0 & 1.3 & 1.0062 & Plio/Pleistocene \\
\hline Liakas & 23 & 125.7 & 2.4 & 14.5 & 4 & 1.0065 & Messinian \\
\hline \multicolumn{8}{|l|}{ Zakynthos } \\
\hline mean & 196 & 146.0 & 0.5 & 4.2 & 1.3 & 1.0082 & \\
\hline Porto Roma & 25 & 173.1 & 2.3 & 4.8 & 3.2 & 1.0070 & $1.03-0.77$ \\
\hline Bochali & 18 & 195.9 & 1.9 & 6.6 & 2.1 & 1.0048 & $1.37-1.24$ \\
\hline Zakynthos Town & 40 & 24.8 & 1.6 & 7.0 & 2.1 & 1.0083 & $1.94-1.44$ \\
\hline Gerakas & 16 & 243.8 & 45.5 & 15.6 & 5.7 & 1.0033 & $1.94-1.61$ \\
\hline Alikanes & 18 & 164.1 & 3.7 & 15.8 & 2.6 & 1.0026 & $3.31-2.73$ \\
\hline Kalamaki Beach & 36 & 156.3 & 9.9 & 5.5 & 3.2 & 1.0064 & $5.95-5.21$ \\
\hline Aghios Sostis & 8 & 168.5 & 0.2 & 14.3 & 4.1 & 1.0071 & Messinian \\
\hline Limnou Keriou (N) & 57 & 330.5 & 3.9 & 3.4 & 1.8 & 1.0103 & $7.24-6.60$ \\
\hline Linmou Keriou (S) & 4 & 160.5 & 6.0 & 20.7 & 7.5 & 1.0068 & Tortonian \\
\hline Ormos Alikon & 33 & 300.4 & 3.0 & 3.8 & 1.4 & 1.0138 & $7.64-7.24$ \\
\hline Vugiato & 14 & 153.8 & 4.6 & 6.6 & 3.7 & 1.0160 & $8.11-7.70$ \\
\hline Marathia & 8 & 319.5 & 10.2 & 21.8 & 4.5 & 1.0124 & Serravalian \\
\hline Lagopodo & 16 & 307.9 & 2.8 & 40.3 & 6.2 & 1.0023 & Early Middle Miocene \\
\hline \multicolumn{8}{|l|}{ Peloponessos } \\
\hline Aghios Andreas & 13 & 345.4 & 3.1 & 56.0 & 4.7 & 1.0010 & Plio/Pleistocene \\
\hline Killini & 63 & 312.0 & 3.1 & 38.4 & 2.7 & 1.0006 & Plio/Pleistocene \\
\hline Pineos & 24 & 316.1 & 6.3 & 48.6 & 5.9 & 1.0007 & Pleistocene \\
\hline Erymanthos & 19 & 181.8 & 2.8 & 64.9 & 4.7 & 1.0004 & Pliocene \\
\hline Neraida & 21 & 347.0 & 5.7 & 13.7 & 3.4 & 1.0017 & Pliocene \\
\hline Krionero & 22 & 287.8 & 6.2 & 22.8 & 4.7 & 1.0009 & Pliocene \\
\hline Vounargon & 9 & 304.6 & 4.2 & 14.7 & 3.6 & 1.0043 & Pliocene \\
\hline Lalas & 10 & 344.6 & 7.5 & 26.9 & 15.7 & 1.0022 & Pliocene \\
\hline Kalithea & 7 & 178.1 & 15.9 & 22.7 & 10.4 & 1.0066 & Pliocene \\
\hline Grillos & 7 & 91.9 & 3.2 & 15.0 & 8.3 & 1.0021 & Upper Pliocene \\
\hline Chrysophylli & 15 & 1.9 & 4.8 & 7.0 & 2.7 & 1.0060 & Pliocene \\
\hline Kefalas & 17 & 53.9 & 0.7 & 18.0 & 2.3 & 1.0015 & Upper Pliocene \\
\hline Gythion & 27 & 280.8 & 4.1 & 34.6 & 5.5 & 1.0018 & Upper Pliocene \\
\hline Glikovrisi & 17 & 239.6 & 0.2 & 17.8 & 4.0 & 1.0015 & Upper Pliocene \\
\hline Megara & 21 & 359.9 & 1.2 & 9.8 & 7.2 & 1.0052 & Plio/Pleistocene \\
\hline Corinth & 11 & 34.0 & 7.5 & 24.5 & 8.1 & 1.0014 & Pleistocene \\
\hline \multicolumn{8}{|l|}{ Milos } \\
\hline Basalt & 7 & 293.1 & 4.4 & 21.9 & 5.8 & 1.0417 & Pliocene \\
\hline Myl10* & 5 & 89.7 & 5.0 & 18.6 & 4.3 & 1.0053 & Plio/Pleistocene \\
\hline Myl11* & 5 & 333.2 & 0.0 & 28.9 & 5.0 & 1.0073 & Plio/Pleistocene \\
\hline Myl15 & 7 & 139.1 & 22.4 & 30.8 & 9.9 & 1.0047 & Plio/Pleistocene \\
\hline Hot & 98 & 240.5 & 15.0 & 40.2 & 12.1 & 1.0004 & Early Pliocene \\
\hline \multicolumn{8}{|l|}{ Kythira } \\
\hline mean & 38 & 100.7 & 5.7 & 14.4 & 4 & 1.0033 & \\
\hline Avlemonas & 12 & 347.9 & 38.3 & 31.2 & 17.4 & 1.0067 & Middle Pliocene \\
\hline Kapsali & 26 & 89.4 & 1.7 & 7 & 2.2 & 1.0030 & Miocene \\
\hline Manitochori & 13 & 114.7 & 6.9 & 29.9 & 6.3 & 1.0034 & Miocene \\
\hline
\end{tabular}




\begin{tabular}{|c|c|c|c|c|c|c|c|}
\hline Locality & $N$ & $\begin{array}{l}D \\
\left({ }^{\circ}\right)\end{array}$ & $\begin{array}{l}I \\
\left({ }^{\circ}\right)\end{array}$ & $\begin{array}{l}\delta D \\
\left({ }^{\circ}\right)\end{array}$ & $\begin{array}{l}\delta I \\
\left({ }^{\circ}\right)\end{array}$ & $L$ & $\begin{array}{l}\text { Age } \\
\text { (Ma) }\end{array}$ \\
\hline \multicolumn{8}{|l|}{ Crete } \\
\hline mean & 93 & 303.2 & 0.9 & 14.3 & 2.9 & 1.0010 & \\
\hline Fortetsa & 7 & 180.7 & 3.6 & 41.1 & 5.3 & 1.0015 & Pliocene \\
\hline Vasileis & 7 & 127.8 & 3.6 & 35.4 & 5.5 & 1.0028 & Pliocene \\
\hline Prassas & 6 & 24.7 & 3.2 & 26.1 & 14.6 & 1.0026 & Mio/Pliocene \\
\hline Chersonissos & 8 & 326 & 0 & 24.3 & 4.7 & 1.0025 & Miocene \\
\hline Gallini & 8 & 310.8 & 9.6 & 32.4 & 8 & 1.0018 & Pleistocene \\
\hline Koutres* & 5 & 303.8 & 15.9 & 38.6 & 16.9 & 1.0008 & Pliocene \\
\hline Moira & 12 & 273.5 & 16.1 & 38.6 & 7.3 & 1.0015 & Plio/Pleistocene \\
\hline Galipe & 7 & 24.7 & 9.5 & 17.6 & 2.9 & 1.0014 & Pliocene \\
\hline Aghios Vlassios & 7 & 106.8 & 12.4 & 9 & 3.9 & 1.0037 & Pliocene \\
\hline Moni Agarathou & 7 & 275 & 4.2 & 18 & 3.9 & 1.0029 & Pliocene \\
\hline Aghios Miron & 7 & 119.9 & 6 & 6.8 & 2.3 & 1.0039 & Messinian \\
\hline Chorio & 8 & 60.9 & 4.1 & 10.5 & 5 & 1.0021 & Pliocene \\
\hline \multicolumn{8}{|l|}{ Kassos } \\
\hline Chelatron all & 16 & 102.4 & 1.7 & 30.9 & 2.6 & 1.0010 & \\
\hline Chelatron $1^{*}$ & 5 & 141.4 & 12.1 & 32.2 & 8.1 & 1.0009 & Miocene \\
\hline Chelatron $2^{*}$ & 5 & 237 & 1.8 & 29.6 & 7 & 1.0017 & Miocene \\
\hline Chelatron $3^{*}$ & 6 & 295.4 & 0.6 & 29.3 & 4.6 & 1.0023 & Miocene \\
\hline Aghios Mamas & 8 & 267.8 & 44.6 & 17.8 & 8.7 & 1.2387 & Miocene \\
\hline \multicolumn{8}{|l|}{ Karpathos } \\
\hline mean & 73 & 64.4 & 0.9 & 14.3 & 1.9 & 1.0012 & \\
\hline Lefkos & 21 & 73.9 & 9.1 & 24.7 & 3.9 & 1.0010 & Plio/Pleistocene \\
\hline Amoopi & 7 & 63.5 & 9.1 & 60.2 & 6.2 & 1.0007 & Pliocene \\
\hline Aghios Ioannis & 28 & 240.1 & 1.3 & 21.6 & 1.9 & 1.0018 & Pliocene \\
\hline Pigadia & 7 & 159.1 & 1.3 & 46.8 & 8.3 & 1.0006 & Pliocene \\
\hline \multicolumn{8}{|l|}{ Rhodos } \\
\hline mean & 137 & 67.5 & 1.1 & 14.3 & 1.6 & 1.0019 & \\
\hline Ancient Kameiros & 8 & 293.5 & 7.4 & 15.2 & 4.1 & 1.0026 & Pliocene \\
\hline $\mathrm{ASH}$ & 21 & 69.6 & 1.6 & 17 & 3.6 & 1.0081 & Oligocene? \\
\hline Falliraki & 8 & 293.9 & 1.4 & 83.1 & 4.2 & 1.0003 & Upper Pliocene \\
\hline Falliraki Beach* & 5 & 267.7 & 0.3 & 51.2 & 9.3 & 1.0030 & Upper Pliocene \\
\hline Kallithea & 6 & 294.4 & 1.9 & 58.6 & 15.5 & 1.0037 & Upper Pliocene \\
\hline Kolimbia & 14 & 30.1 & 0 & 48.3 & 4.4 & 1.0018 & Uppermost Pliocene \\
\hline Ladiko & 9 & 53.7 & 1.3 & 34.3 & 4.5 & 1.0031 & Pliocene \\
\hline Pefki Beach & 13 & 92 & 12.5 & 19.1 & 2.8 & 1.0027 & Upper Plio/Pleistocene \\
\hline Pylonas & 9 & 302.9 & 3 & 40.1 & 6.9 & 1.0014 & Uppermost Pliocene \\
\hline Skaloniti & 7 & 88.7 & 15.9 & 60.5 & 11.7 & 1.0010 & Pliocene \\
\hline Tsambika & 8 & 118.1 & 1.1 & 46.7 & 4 & 1.0013 & Pliocene \\
\hline Vagies* & 4 & 41.8 & 2.7 & 48.9 & 9.3 & 1.0056 & Upper Pliocene \\
\hline Appolakkia & 25 & 232.4 & 3.2 & 17.6 & 4 & 1.0022 & Pliocene \\
\hline
\end{tabular}

\section{References}

[1] C. Laj, M. Jamet, D. Sorel, J.P. Valente, First paleomagnetic results from Mio-Pliocene series of the Hellenic sedimentary arc, Tectonophysics 86 (1982) 45-67.

[2] C. Kissel, C. Laj, The Tertiary geodynamical evolution of the Aegean arc: a paleomagnetic reconstruction, Tectonophysics 146 (1988) 183-201.

[3] A. Morris, M. Anderson, First paleomagnetic results from the Cycladic Massif, Greece, and their implications for
Miocene extension directions and tectonic models in the Aegean, Earth Planet. Sci. Lett. 142 (1996) 397-408.

[4] D. Avigad, G. Baer, A. Heimann, Block rotations and continental extension in the central Aegean Sea: paleomagnetic and structural evidence from Tinos and Mykonos (Cyclades, Greece), Earth Planet. Sci. Lett. 157 (1998) 23-40.

[5] C.E. Duermeijer, W. Krijgsman, C.G. Langereis, J.H. Ten Veen, Post early Messinian counter-clockwise rotations on Crete: implications for the Late Miocene to Recent kine- 
matics of the southern Hellenic Arc, Tectonophyics 298 (1998) 177-189.

[6] C.E. Duermeijer, W. Krijgsman, C.G. Langereis, J.E. Meulenkamp, M.V. Triantaphyllou, W.J. Zachariasse, A middle Pleistocene clockwise rotation phase of Zakynthos (Greece) and implications for the evolution of the western Aegean arc, Earth Planet. Sci. Lett. 173 (1999) 315331.

[7] H.A. Jonkers, Pliocene benthonic foraminifera from homogeneous and laminated marls on Crete, Utr. Micropal. Bull. vol. 31, 1984, 179 pp.

[8] J. Aubouin, M. Bonneau, J. Davidson, P. Leboulenger, S. Matesco, A. Zambetakis, Esquisse structurale de l'arc égéen externe: des Dinarides aux Taurides, Bull. Soc. Geol. Fr. 18 (1976) 327-336.

[9] J.R. Underhill, Triassic evaporites and Plio-Quaternary diapirism in western Greece, J. Geol. Soc. Lond. 145 (1988) 269-282.

[10] J. Hageman, Benthic foraminiferal assemblages from PlioPleistocene open bay to lagoonal sediments of the western Peloponessos (Greece), Utr. Micropal. Bull. vol. 20, 1979, $171 \mathrm{pp}$.

[11] R.E.L. Collier, C. Dart, Neogene to Quaternary rifting, sedimentation and uplift in the Corinth Basin, Greece, J. Geol. Soc. Lond. 148 (1991) 1049-1065.

[12] X. Le Pichon, J. Angelier, The Hellenic arc and trench system: a key to the neotectonic evolution of the eastern Mediterranean area, Tectonophysics 60 (1979) 1-42.

[13] J.-L. Mercier, N. Delibassis, A. Gauthier, J.-J. Jarrige, F. Lemeille, H. Philip, M. Sébrier, D. Sorel, La néotectonique de l'Arc égéen, Rev. Geol. Dyn. Geogr. Phys. 21 (fasc. 1) (1979) 67-92.

[14] J. Angelier, N. Lybéris, X. Le Pichon, E. Barrier, Ph. Hunchon, The tectonic development of the Hellenic arc and the Sea of Crete: a synthesis, Tectonophysics 86 (1982) 159-196.

[15] F. Horner, R. Freeman, Paleomagnetic evidence from pelagic limestones for clockwise rotation of the Ionian zone, western Greece, Tectonophysics 98 (1985) 11-27.

[16] C. Kissel, C. Laj, C. Müller, Tertiary geodynamical evolution of northwestern Greece: paleomagnetic results, Earth Planet. Sci. Lett. 72 (1985) 190-204.

[17] M.V. Triantaphyllou, Biostratigraphical and ecostratigraphical observations based on calcareous nannofossils, of the eastern Mediterranean Plio-Pleistocene deposits, Gaia No. 1, PhD thesis, Athens University, 1996, 229 pp.

[18] D.P. Kondopoulo, S.B. Pavlides, Paleomagnetic and neotectonic evidence for different deformation patterns in the south Aegean volcanic arc: the case of Melos island, Int. Earth Sci. Congr. Aegean Regions Proc. 1 (1990) 210 223.

[19] C. Kissel, C. Laj, A. Malzaud, First paleomagnetic results from Neogene formations on Evvia, Skyros and the Volos region and the deformation of Central Aegea, Geophys. Res. Lett. 13 (1986) 1446-1449.

[20] C. Laj, A.J. Gauthier, B. Keraudren, Mise en évidence d'une rotation plio-quaternaire de l'île de Rhodos
(Grèce): résultats préliminaires, Réun. Ann. Sci. Terre 6e, Orsay (1978) 224.

[21] C. Kissel, A. Poisson, Etude paléomagnétique préliminaire des formations cénozoïques des Bey Daglari (Taurides occidentale, Turquie), C.R. Acad. Sci. Paris 304, II (8) (1987) 343-348.

[22] L.J. Lourens, A. Antonarakou, F.J. Hilgen, A.A.M. Van Hoof, C. Vergnaud-Grazzini, W.J. Zachariasse, Evaluation of the Plio-Pleistocene astronomical timescale, Paleooceanography 11 (1996) 391-413.

[23] H.-G. Kahle, C. Straub, R. Reilinger, S. McClusky, R. King, K. Hurst, G. Veis, K. Kastens, P. Cross, The strain rate field in the eastern Mediterranean region, estimated by repeated GPS measurements, Tectonophysics 294 (1998) 237-252.

[24] R. Davies, P. England, B. Parsons, H. Billiris, D. Paradissis, G. Veis, Geodetic strain of Greece in the interval 1892-1992, J. Geophys. Res. 102 (1997) 24571-24588.

[25] P.J. Clarke, R.R. Davies, P.C. England, B. Parsons, H. Billiris, D. Paradissis, G. Veis, P.A. Cross, P.H. Denys, V. Ashkenazi, R. Bingley, H.-G. Kahle, M.-V. Müller, P. Briole, Crustal strain in central Greece from repeated GPS measurements in the interval 1988-1997, Geophys. J. Int. 135 (1998) 195-214.

[26] P.R. Cruddace, P.A. Cross, G. Veis, H. Billiris, D. Paradissis, J. Galanis, H. Lyon-Caen, P. Briole, B.A.C. Ambrosius, W.J.F. Simons, E. Roegies, B. Parsons, P. England, H.-G. Kahle, M. Cocard, P. Yannick, G. Stavrakakis, P. Clarke, M. Lilje, An interdisciplinary approach to studying seismic hazard throughout Greece, IUGG Abstracts B (1), 1999, p. 78.

[27] P.J. Clarke, R.R. Davies, P.C. England, B.E. Parsons, H. Billiris, D. Paradissis, G. Veis, P.H. Denys, P.A. Cross, V. Ashkenazi, R. Bingley, Geodetic estimate of seismic hazard in the Gulf of Korinthos, Geophys. Res. Lett. 24 (1997) 1303-1306.

[28] W. Spakman, M. Nyst, A new approach to the inversion of relative displacement data, Geophys. Res. Abstr. 1 (1998) 203.

[29] L. Jolivet, J.-P. Brun, P. Gautier, S. Lallemant, M. Patriat, 3D-kinematics of extension in the Aegean region from the early Miocene to the Present, insights from the ductile crust, Bull. Soc. Geol. Fr. 165 (1994) 195-209.

[30] R. Armijo, B. Meyer, G.C.P. King, A. Rigo, D. Papanastassiou, Quaternary evolution of the Corinth Rift and its implications for the Late Cenozoic evolution of the Aegean, Geophys. J. Int. 126 (1996) 11-53.

[31] J.L. Mercier, D. Sorel, K. Simeakis, Changes in the state of stress in the overriding plate of a subduction zone; the Aegean arc from the Pliocene to the present, Ann. Tecton. 1 (1987) 20-39.

[32] R. Westaway, Quaternary elevation change of the Gulf of Corinth in central Greece, Philos. Trans. R. Soc. Lond. A 354 (1996) 1125-1164.

[33] C. Kissel, E. Barrier, C. Laj, T.-Q. Lee, Magnetic fabric in 'undeformed' marine clays from compressional zones, Tectonics 5 (1986) 769-781. 
[34] L. Gilbert, K. Kastens, K. Hurst, D. Paradissis, G. Veis, H. Billiris, W. Höppe, W. Schlüter, Strain results and tectonics from the Aegean GPS experiment, EOS, Suppl. April 19, 1994, 116 pp.

[35] H. Lyon-Caen, R. Armijo, J. Drakopoulos, J. Baskoutass, N. Delibassis, R. Gaulon, V. Kouskouna, J. Latoussakis, K. Makropoulos, P. Papadimitriou, D. Papanastasiou, G. Pedotti, The 1986 Kalamata (South Peloponessos) earthquake detailed study of a normal fault, evidences for eastwest extension in the Hellenic arc, J. Geophys. Res. 93 (1988) 14967-15000.

[36] D. Hatzfeld, M. Besnard, K. Makropoulos, P. Hatzidimitriou, Microearthquake seismicity and fault-plane solutions in the southern Aegean and its geodynamic implications, Geophys. J. Int. 115 (1993) 799-818.

[37] R. Armijo, H. Lyon-Caen, D. Papanastassiou, East-west extension and Holocene normal-fault scarps in the Hellenic arc, Geology 20 (1992) 491-494.

[38] C. Baker, D. Hatzfeld, H. Lyon-Caen, E. Papadimitriou, A. Rigo, Earthquake mechanisms of the Adriatic Sea and Western Greece: implications for the oceanic subductioncontinental collision transition, Geophys. J. Int. 131 (1997) 559-594.

[39] X. Le Pichon, N. Chamot-Rooke, S. Lallemant, R. Noomen, G. Veis, Geodetic determination of the kinematics of central Greece with respect to Europe: Implications for eastern Mediterranean tectonics, J. Geophys. Res. 100 (1995) 12675-12690.

[40] S. Cianetti, P. Gasparini, M. Boccaletti, C. Giunchi, Reproducing the velocity and stress fields in the Aegean region, Geophys. Res. Lett. 24 (1997) 2087-2090.

[41] P.Th. Meijer, M.J.R. Wortel, Present-day dynamics of the Aegean region: A model analysis of the horizontal pattern of stress and deformation, Tectonics 16 (1997) 879-895.
[42] P.Th. Meijer, M.J.R. Wortel, Temporal variation in the stress field of the Aegean region, Geophys. Res. Lett. 23 (1996) 439-442.

[43] M.J.R. Wortel, W. Spakman, Structure and dynamics of subducted lithosphere in the Mediterranean region, Proc. K. Ned. Akad. Wet. 95 (1992) 325-347.

[44] W. Spakman, S. Van der Lee, R. van der Hilst, Traveltime tomography of the European-Mediterranean mantle down to 1400 km, Phys. Earth Planet. Inter. 79 (1993) 374.

[45] M.J. van der Meulen, J.E. Meulenkamp, M.J.R. Wortel, Lateral shifts of Apenninic foredeep depocentres reflecting detachment of subducted lithosphere, Earth Planet. Sci. Lett. 154 (1998) 203-219.

[46] D. Rio, I. Raffi, C. Villa, Pliocene-Pleistocene calcareous nannofossil distribution patterns in the Western Mediterranean, Proc. ODP Sci. Res. 107 (1990) 513-533.

[47] C.G. Langereis, M.J. Dekkers, G.J. de Lange, M. Paterne, P.J.M. van Santvoort, Magnetostratigraphy and astronomical calibration of the last $1.1 \mathrm{Myr}$ from an eastern Mediterranean piston core and dating short events in the Bruhnes, Geophys. J. Int. 129 (1997) 75-94.

[48] L.J. Lourens, F.J. Hilgen, I. Raffi, Base of large geophyrocapsa and astronomical calibration of early Pleistocene sapropels in site 967 and hole 969D: solving the chronology of the Vrica section (Calabria, Italy), ODP Sci. Res. 160 (1998) 191-197.

[49] J.A. Broekman, Sedimentation and paleoecology of Pliocene lagoonal-shallow marine deposits on the island of Rhodos (Greece), Utr. Micropal. Bull. vol. 8, 1974, 148 pp.

[50] V. Jelinek, The statistical theory of measuring anisotropy of magnetic susceptibility of some igneous and metamorphic rocks, Geofyzika Brno, 1977. 